\title{
LEARNING TO TEACH IN THE NZ ITP SECTOR: LESSONS FROM LITERATURE
}

\author{
Julia Walne
}

\section{CONTEXT}

Now more than ever, Institutes of Technology and Polytechnics (ITPs) are central to enabling New Zealand to be competitive in a global market as both an economic force and as a quality, skills-based education provider. There is growing evidence to suggest that practitioners in this vocational sector need to have a "sophisticated pedagogical repertoire" (Guthrie, 2010, p. 12) and be skilled at pedagogical decision-making in both learner-centred and workbased practices (Brown, 2017; Guthrie, 2010; Lucas, Spencer, \& Claxton, 2012). Despite this growing expectation on teachers' performance in the New Zealand ITP sector (Messman, Mulder, \& Gruber, 20I0) and a reported correlation between quality vocational provision and teaching competence (Guthrie, 2010), there is limited research on how best to support novice ITP teachers to learn to teach. As yet, there is no national framework of competence for ITP teachers and no requirement for teachers in this sector to hold a teaching qualification. As a result, polytechnics tend to employ new teaching staff members on the basis of their domain-specific knowledge and skills and then expect them to gain a formal teaching qualification whilst doing the job of teaching.

Otago Polytechnic is the only ITP that requires its teachers to hold a Level 7 teaching qualification and new academic staff members are contractually required to complete the Graduate Diploma in Tertiary Education (GDTE) within two years. The first iteration of the GDTE was approved in 2012 and there have been a number of iterations and many lessons learned since then. Past stakeholder feedback has mirrored the findings of research on traditional teacher education and highlighted a mismatch between the pedagogical knowledge espoused in formal programmes of study and what learners perceive as valuable teaching knowledge in their own contexts (Bound, 20II; Dymock \& Tyler, 20I8; Korthagen, Loughran, \& Russell, 2006). As a result, the GDTE has integrated a work-based learning approach that situates learning within the learners own teaching context. However, this approach is not without risk as it is commonly agreed that the social bonds, collegial interactions and socio-cultural practices can constrain learning and development of teaching practice. Therefore, the purpose of this article is to see if any further lessons can be learned about potential barriers between formal programmes of study and informal workplace learning. It first presents a brief review of recent research on learning to teach, exploring five key themes relevant to the vocational sector. It then presents a brief discussion of the key considerations before proposing that learning partnerships could integrate the GDTE within specific teaching contexts and bridge the gap between theory and practice by leveraging the inherent value of informal learning in the workplace. 


\section{BRIEF REVIEW OF LITERATURE}

\section{Formal Learning}

For many years, research on teacher education development drew on cognitive theory to promote traditional teacher education that taught theory for application to practice (Opfer \& Pedder, 20II). However, recent studies appear to agree that traditional approaches are ineffective because they fail to recognise the importance and influence of the socio-cultural context in which each individual teacher is situated (Opfer \& Pedder, 20II; Viscovik, 2005, Wenger, 1998). Furthermore, there is general consensus that tensions arise from novice teachers' existing conceptions of teaching and the pedagogical practice espoused in traditional programmes (Bound, 20ll; Dymock \& Tyler, 2018; Korthagen et al., 2006). Through prior experiences in occupational contexts, novice teachers in the ITP sector will have developed not only considerable occupational knowledge, but also strongly-held conceptions of teaching and learning (Aderibigbe, Colucci-Gray, \& Gray, 2016; Darling-Hammond, 2006).

Robson (2002) finds that vocational teachers' ways of learning are particularly influenced by how they developed their occupational knowledge and skills prior to becoming a teacher. He also finds that they tend to value occupational knowledge more highly than teaching knowledge. Transformative learning theory identifies such conceptions as barriers to learning and acknowledges that where there is a mismatch between conceptions of teaching and learning and the reality of a formal programme, learners will experience dissonance and may disengage (Mezirow, 1990; Zepke, 201I). These barriers mean that formal programmes are rarely effective in developing teaching practice (Opfer \& Pedder, 20II).

Recent research draws on transformative learning theory to suggest that teaching about teaching adopts a bottomup approach that begins with an examination of existing conceptions and how they might enable or constrain both learning and teaching practice (Forzani, 2014; McDonald, Kazemi, \& Kavanagh, 2013; Peercy \& Troyan, 2017). As a result, they call for teacher education programmes to embrace more practice-based pedagogies that recognise that "learning is an active, constructive process that is heavily influenced by an individual's existing knowledge and beliefs and is situated in particular contexts" (Borko \& Putnam, as cited in Feiman-Nemser, 2008, p. 700).

\section{Informal Learning}

Hoekstra and Korthagen (20II) define informal learning as any learning that takes place without an organised learning community or planned pathway. Much of the research shows that teachers value informal learning and believe that their expertise develops through every day experiences of teaching (Viscovik, 2005). Kwakman (2003) suggests that this is due to an assumption "that learning is embedded within the trial and error of everyday activities" (p. 166). This assumption is rooted in theories of adult learning and the belief that adults learn by reflecting on experiences to construct new meaning (Dewey, as cited in Harris, 201I). However, there is evidence that such reflection does not naturally occur and that informal learning frequently results in little awareness of learning and primarily tacit knowledge (Eraut, 2004; Hoekstra, Brekelmans, Beijard, \& Korthagen, 2009). Furthermore, the evidence suggests that tacit knowledge limits development of teaching practice (Brockbank \& McGill, 2006; Korthagen \& Kessels, 1999).

Darling-Hammond and Bransford (2005) claim that even when teachers do reflect on their everyday teaching experiences, there is no guarantee that they will learn from it. Gelfuso and Dennis (2014) find that novice teachers often reflect in isolation, which leads to learning that is based on existing beliefs about teaching. Jarvis (2004) discusses this phenomenon as non-learning, which is similar to Habermas' concept of non-reflexive learning whereby learning occurs without critical discussion (Habermas, as cited in Brookfield, 2005). In order to act as reflective practitioners, novice teachers need to compare past and current experience in light of educational theory, in order to make reasoned decisions about approaches to teaching (Harrison, Lawson, \& Wortley, 2005; Boud, 2000; Timperley, Wilson, Barrar, \& Fung, 2008). Gelfuso and Dennis (2014) recommend that novice teachers 
are supported to critically examine their practice through focused and collaborative discussion on practice in the presence of "knowledgeable others" (p. I). Hopper (200I) recommends evolutionary workplace mentoring to foster the growth of autonomous, reflective practitioners. Evolutionary mentoring relationships are described as "between equals in which one or more of those involved is enabled to: increase awareness, identify alternatives, initiate action, and develop themselves" thus identifying the need for a non-hierarchical, reciprocal and enabling partnership (Hay, as cited in Brockbank \& McGill, 2006, p.67).

\section{Work-based Learning}

Much of the recent research on teacher learning emphasises the social and situated nature of teacher learning and highlights the potential for inevitable workplace variances and different socio-cultural contexts to variously influence learning (Andersson \& Kopsen, 2015; Blömeke \& Kaiser, 2017; Eraut, 2007). A common theme arising is the influence that collegial interactions can have on learning (see, for example, Koffeman \& Snoek, 20I8; Opfer \& Pedder, 20II). A review by Kyndt, Gijbels, Grosemans, and Donche (2016) identifies that colleagues' attitudes and dispositions towards learning influence novice teachers' engagement in learning opportunities. They also find that the "dominant norms, values and traditions" within the socio-cultural context influence what is learned (p. II33). More specifically, Maxwell (2010) finds that learning is influenced by naturally occurring interactions with colleagues and suggests that novice teachers need to be given support to challenge any collegial interaction with the potential to inhibit learning. Harris (20II) suggests that to develop a more sophisticated repertoire of pedagogical practices, novice teachers need to broaden their experiences of teaching through observation of expert teachers outside of their everyday teaching contexts. In this context, expert teachers are considered able to articulate the "trial and error" of teaching by making their pedagogically-informed decision-making explicit to less experienced teachers (Hattie \& Clinton, 2008, p. 242).

Singularly, Maxwell (2010) seeks further understanding of the in-service nature of learning to teach in the vocational sector and finds that beliefs and prior experiences and collegial interactions have a significant influence on engagement in learning. As a result, she calls for better integration between formal and informal opportunities for workplace learning through "guided participation in an intentional curriculum" (p. 185). Maxwell's use of the term 'guided participation' reinforces Gelfuso and Dennis' idea that novice teachers should learn alongside more knowledgeable practitioners.

\section{Teacher Identify Development}

Teacher identity development emerges as a central idea in the literature on teacher learning over the last 20 years (Beijaard \& Meijer, 2017). Research from a socio-cultural perspective tends to agree that teacher identity is dynamic and under construction through continuous interpretation of both current and future perceptions of self-as-teacher (Akkerman \& Meijer, 20II; Van Lankveld, Schoonenboom, Volman, Croiset, \& Beishuizen, 20I7). Research in the broader teacher education domain highlights the importance of a secure and coherent teacher identity as a platform for the informed pedagogical decision-making necessary for highly-skilled practitioners. Yet there is growing evidence that vocational teachers identify more closely with their previous occupations than they do with the teaching profession, and that they draw on experiences of learning and teaching in occupational contexts to inform their teaching practice.

Tang (2006) describes the process of learning to teach as constructing "the teaching self in the professional artistry of teaching" (p. 5l) and finds that novice teachers do not yet have a secure identity but one that is only partly-formed, arising from a "plethora of unarticulated and unexamined beliefs about teaching, learning and the self as teacher" (Bullough \& Gitlin, as cited in Tang, 2004, p. 187). The research commonly acknowledges that current contextual factors, including collegial interactions, exert a considerable influence over this process (Beauchamp \& Thomas, 2009; Grier \& Johnston, 2009). Collegial relationships are often valued by novice teachers because they support socialisation into the teacher profession (Grier \& Johnson, 2009). However, such social and 
occupational bonds can influence perceptions of what is valuable knowledge in their context and influence novice teachers' engagement in formal learning (Hansman, 2008), which has the potential to lead to identity ambiguity (McNaughton \& Billot, 2016; Trautwein, 20l8).

In order to promote development of a teacher identity, Sutherland and Markauskaite (2012) discuss use of authentic learning experiences to motivate novice teachers and support them to develop their practice through engagement in real "routines, rituals and conventions" (p. 750). Similarly, Grier and Johnson (2009) suggest the development of mediated experiences that facilitate participation in "joblike", "accountability environments" but are supported by modelling and mentorship (p. 57). It is interesting that the term participation is used again here and suggests novice teachers need guidance from more experienced teachers within those environments.

\section{Communities of Practice}

A review of research on teacher professional learning in the UK by Opfer and Pedder (201I) recommends integration of a Communities of Practice (CoP) framework to represent the interrelationships between the individual, the teaching community, and their specific teaching context. They describe these interrelationships as the "systems of influence in a teacher's world" (p. 368). This study is one of a growing number emerging from Europe over the last 20 years that explore the potential of a CoP framework for teacher learning in either higher or secondary contexts. In contrast, Viscovik (2005) studies aspects of informal learning in three different tertiary organisations in New Zealand. Through the case studies that emerge, Viscovik highlights the potential of the CoP framework for teacher learning in the New Zealand tertiary sector and argues that institutions should draw on situated and social learning. However, the nature of these learning communities and how best to cultivate them is still contested in the literature.

Early conceptualisations of CoPs perceive them as naturally occurring, voluntarily and unstructured (Wenger, 1998). More recent studies suggest that CoPs can be intentionally nurtured as facilitated learning environments that support participants to make tacit knowledge more explicit (Reaburn \& McDonald, 20 I7; Sanchez-Cardona, Sanchez-Lugo, \& Velez-Gonzalez, 2012). However, the growing number of studies, mainly from the compulsory and Higher Education (HE) contexts, that explore the cultivation of CoPs for teacher learning present conflicting messages. Some researchers question the overly collegial view of CoPs and argue that much of the research ignores the potential for relationships to influence negatively or inhibit learning (for example Annala \& Mäkinen, 2017). However, others find that CoPs can promote collaboration, reduce isolation and support engagement (Patton \& Parker, 2017; Retna \& Ng, 20I0; Viscovik, 2005).

\section{KEY CONSIDERATIONS}

The research shows that conceptions of teaching and learning can impact on learning in two ways. Firstly, novice teachers in the ITP sector often come to teaching with considerable occupational expertise and strongly-held, partly-formed conceptions of teaching. These conceptions act like a filter on how novice teachers interpret and learn from their everyday experiences of teaching. Secondly, these conceptions can affect engagement in formal learning opportunities because of a perceived mismatch between espoused pedagogical approaches and existing knowledge. Zepke (2010) discusses this unwillingness to engage and suggests that it occurs because they are not ready to learn. Despite this evidence that existing conceptions can constrain both learning, these conceptions are often left unexamined to be continually reinforced through workplace practices and interactions. As a result, a bottom-up approach is suggested that begins with what a collaborative deconstruction of beliefs, assumptions and expectations, not just of teaching but of learning, including perceptions of self as a learner (Forzani, 20I4; McDonald et al., 2013; Peercy \& Troyan, 2017).

Whilst the first course in the GDTE begins by asking learners to reflect on what they already know about teaching and how they know it, time constraints limit the depth of discussion. In addition, conceptions evidence an affective 
dimension to teaching as they are highly personal and therefore often tied to strong feelings and emotions. Furthermore, when conceptions are established in prior occupational contexts and occupational knowledge is perhaps valued more highly than teaching knowledge, there is potential for dissonance that might impact on participation. Therefore, a key consideration is how best to establish a trust environment in which beliefs and assumptions can be openly shared and safely and constructively challenged.

A key outcome of the GDTE is that graduates can act as reflective practitioners. Whilst it is often assumed that novice teachers instinctively reflect on their experiences and question assumptions or misconceptions, research identifies that the ability to reflect on teaching experiences is a key limiting factor to learning. From a sociocultural perspective, much of the research advocates for opportunities to collaborate with peers in the analysis and interpretation of teaching experiences in presence of a knowledge other (Gelfuso \& Dennis, 2014; Grier \& Johnson, 2009). The GDTE is underpinned by a practice-based pedagogy and therefore recognises the importance of reflection on practice for the development of practice. It integrates opportunities for learners to try out new pedagogical approaches in their classrooms and then to reflect on the experience. Learners are given probing and exploratory questions to support them to examine the experience, followed by facilitated opportunities to participate within a learning community and collaboratively analyse and interpret the experiences with other learners and a GDTE facilitator. This is similar to the notion of learning communities (Dirksen, Klassen, \& Daniels, 2017; Shulman \& Shulman, 2004).

However, research also suggests that novice teachers' practices are deeply informed by past and present workplace practices and strongly influenced by collegial interaction within specific teaching contexts. This means that the perceived value of the GDTE facilitator acting as a knowledgeable other may well be tempered by the learners' perceptions of what is valuable knowledge in their context. Therefore, whilst GDTE facilitators do have considerable knowledge of learning and teaching, it must be acknowledged that learners may not consider this to be valuable knowledge. Thus, a second consideration is how to increase the perceived value of teaching knowledge in order to promote reflection for meaningful learning.

As previously discussed, novice teachers' practices may be deeply informed by the ways in which they were taught in prior workplaces. Additionally, conceptions are strongly-held and often reinforced through the dominant discourse in their specific teaching contexts. These findings suggest that novice teachers must broaden their experiences of teaching in order to expand their own conceptions. This view is supported by Dewey, who believed that observations of others' teaching practice are central to teacher development (Dewey, as cited in Harris, 20II). Harris (20II) suggests that the knowledge required for skilled teaching practice needs to be articulated by an expert teacher. Boud (2000) identifies that expert teachers possess not only extensive teaching knowledge but are also able to make this knowledge explicit and therefore accessible to novice teachers. Hattie and Clinton (2008) refer to this process as "a staccato of trial and error" (p. 242) whereby teaching knowledge and reasoned decision-making is made explicit as they deconstruct and reconstruct their teaching practice, thus supporting novice teachers to make connections between what they have observed and the underpinning pedagogy.

Whilst novice teachers may observe some of their colleagues as part of an induction process, or through peer observation activities that are integrated within the GDTE, these opportunities do not necessarily broker access to an expert teacher. This means that where observed practice fits with a novice teacher's existing conceptions, they may well replicate it without question, or where it does not fit, simply reject it as not relevant in their context. Thus, a third consideration is how best to broker access, not just to observations of teaching, but observations of expert teachers who can make the reasoning behind their pedagogical decision-making explicit.

The research suggests that development of a teaching identity is important to the development of teaching practice and yet it also finds that vocational teachers often identify more strongly with their prior occupation than they do with teaching. There is evidence that the socio-cultural context may influence the outcomes of informal learning and suppress emerging teaching identities, particularly when the dominant discourse is occupational rather 
than teaching knowledge. Research suggests that authentic, mediated learning experiences are facilitated in realworld work environments but that they need to be supported by mentorship (Grier and Johnson, 2009; Maxwell, 2010). The GDTE integrates authentic learning activities and subsequently facilitates collaborative discourse and reflection across contexts, within a more formal learning environment. However, it does not currently support the on-going mentorship in the specific work environment that is required to leverage the perceived value of informal learning and to challenge non-learning. The final consideration then is how to mediate the formal learning opportunities that are integrated into the GDTE with the informal learning through mentorship within the specific teaching context.

These four key considerations highlight potential barriers between formal learning and informal learning in close knit workplace communities. It is clear that whilst a perceived separation of formal learning in the GDTE and informal learning in the workplace continues, tensions will continue to arise. Therefore, the GDTE facilitators need to find a way to leverage the value inherent in informal learning and the strong social bonds within workplace communities. The research suggests that integrating a CoP framework would support situated and social learning and enable discursive conversations to make explicit the tacit knowledge arising from informal learning in the workplace. However, although research indicates that the some of the norms associated with CoPs can be used to create more effective learning environments, it also presents conflicting messages and raises significant questions about how best to establish and facilitate these communities. Furthermore, it queries the collegial view of CoP relationships and suggest that CoP relationships can perpetuate tacit knowledge and can negatively influence or inhibit learning (for example, Annala \& Mäkinen, 20I7).

Therefore, rather than setting up intentional CoPs, GDTE facilitators could draw on the norms associated with traditional CoPs, whereby novice workers work alongside more experienced others to establish learning partnerships. However, learning partnerships in this context would differ from the traditional socio-cultural, one-to-one partnerships also to a GDTE facilitator. A triumvirate of novice teacher, more experienced teacher or learning leader from the learner's specific teaching context, and a GDTE facilitator would work together to situate the GDTE within the workplace. Acknowledging that all partners come to the relationship with significant life experiences to share, and established conceptions and expectations of both learning and teaching suggests these partnerships would be non-hierarchical and reciprocal. Similar to evolutionary mentoring relationships, as described by Hay (1995), these partnerships could create the high trust environment needed to both challenge and support a novice teacher.

Learning partners could share the roles of workplace mentor and GDTE facilitator to begin to break down the barriers between formal learning and informal workplace learning and increase the perceived value of teaching knowledge. Partnerships could come together to broker access to expert teachers and lead post-observation conversations that explore the expert teachers' knowledge and reasoned decision-making and support novice teachers to make connections between theory and practice. In addition, they could situate learning in the learner's own experiences by providing ongoing mentorship: mediating GDTE learning experiences, challenging learners to analyse their experiences, and sharing and constructing new pedagogical knowledge as and when it arises. As knowledgeable others, the more experienced partners could share valuable pedagogical knowledge to support novice teachers to make connections between theory and practice within their own teaching context, thus developing more reasoned pedagogical content knowledge (Van Driel \& Berry, 2012).

\section{CONCLUSION}

It is clear that learning to teach in-service is a complex process involving interplay between formal and informal learning and neither of these approaches present a ready-made easy answer to learning about teaching. Instead, each has potential to promote and constrain learning. Whilst the new iteration of the GDTE integrates a more practice-based pedagogy in order to situate learning experiences within the work environment, a review of the 
literature suggests that barriers are likely to exist between formal and informal learning, and the perceived value of teaching knowledge. The establishment of learning partnerships between novice teachers who are enrolled in the GDTE, more experienced teachers or learning leaders from their specific teaching context, and GDTE facilitators could more closely situate formal learning within the workplace context and leverage the value placed on informal learning and the influence of workplace communities.

Julia Walne has 30 years' experience working across educational sectors, the last 12 of which have been in academic capability development and advisory roles within the ITP sector. She has broad experience in the design, development and facilitation of tertiary teaching education programmes.

(10) https://orcid.org/0000-0002-2646-7237

\section{REFERENCES}

Aderibigbe, S., Colucci-Gray, L., \& Gray, D.S. (2016). Conceptions and expectations of mentoring relationships in a teacher education reform context. Mentoring \& Tutoring: Partnership in Learning, 24(I), 8-29.

Akkerman, S. F., \& Meijer, P. (20II). A dialogical approach to conceptualizing teacher identity. Teaching and Teacher Education, 27(2), 308-319. https://doi.org/10.1016/j.tate.2010.08.013

Andersson, P., \& Kopsen, S. (2015). Continuing professional development of vocational teachers: Participation in a Swedish national initiative. Empirical Research in Vocational Education and Training, 7(7), I-20. https://doi.org/I0.1I86/s4046I-015$0019-3$

Annala, J., \& Mäkinen, M. (2017). Communities of practice in Higher Education: Contradictory narratives of a university-wide curriculum reform. Studies in Higher Education, 42(II), 194I-1957. https://doi.org/I0. I080/03075079.20 I5. I 25877

Beauchamp, C., \& Thomas, L. (2009). Understanding teacher identity: An overview of issues in the literature and implications for teacher education. Cambridge Journal of Education, 39(2), 175- 189. https://doi.org//0.1080/03057640902902252

Beijaard, D., \& Meijer, P. (2017). Developing the personal and professional in making a teacher identity. In D. Clandinin, \&J. Husu (Eds.), The SAGE handbook of research on teacher education (Vol.I, pp. 177-192). London: SAGE Publications Ltd.

Blömeke, S., \& Kaiser, G. (2017). Understanding the development of teachers' professional competencies as personally, situationally and socially determined. In D. Clandinin, \& J. Husu (Eds.), The SAGE handbook of research on teacher education (Vol. 2, pp. 783-802). United Kingdom: SAGE Publications Ltd. Retrieved from https://www.duo.uio.no/bitstream/ handle//0852/59437///Clandinin_Styled_Chap45_SB.pdf

Boud, D. (2000). Sustainable assessment: Rethinking assessment for the learning society. Studies in Continuing Education, 22(2), |5|-167.

Bound, H. (20II). Vocational education and training teacher professional development: tensions and context. Studies in Continuing Education, 33(2), 107-119. https://doi.org/I0.1080/0158037X.2011.554176

Brockbank, A., \& McGill, I. (2006). Facilitating reflective learning: Coaching, mentoring and supervision. London: Kogan Page.

Brookfield, S. (2005). The power of critical theory for adult learning and teaching. England: Open University Press.

Brown, M. (2017). The tradies' entrance into teaching: The challenges in designing teacher education for vocational education and training in schools. International Journal of Training Research, I5(I), 7I-84. https://doi.org/I 0.1080/I4480220.20 I7.1350199

Darling-Hammond, L. (2006). Powerful teacher education. San Francisco, USA: Jossey-Bass.

Darling-Hammond, L., \& Bransford, J. (2005). Preparing teachers for a changing world. What teachers should learn and be able to do. San Francisco: Jossey-Bass.

Dirksen, T. L., Klassen, R. M, \& Daniels, L. M. (2017). Motivation and Collaboration: The keys to a developmental framework for teachers' professional learning. Teaching and Teacher Education, 67, 53-66. https://doi.org/l0.1016/j.tate.2017.05.01I

Dymock, D., \& Tyler, M. (2018). Towards a more systematic approach to continuing professional development in vocational education and training. Studies in Continuing Education, 40(2), 198-211. https://doi.org//0.1080/0I58037X.2018.1449102

Eraut, M. (2004). Informal learning in the workplace. Studies in Continuing Education, 26(2), 247-273. https://doi.org//0.1080/ 158037042000225245 
Eraut, M. (2007). Learning from other people in the workplace. Oxford Review of Education, 33(4), 403-422. https://doi.org/ 10.1080/0305498070|425706

Feiman-Nemser, S. (2008). Teacher learning: how do teachers learn to teach? In M.Cochran-Smith, S. Feiman-Nemser, D. McIntyre \& K. Demers (Eds.), Handbook of research on teacher education: Enduring questions in changing contexts (3rd ed., pp. 693-846). Routledge. https://doi.org/l0.4324/9780203938690

Forzani, F. M. (2014). Understanding "core practices" and "practice-based" teacher education: Learning from the past. Journal of Teacher Education, 65(4), 357-368. https://doi.org/I0.1177/0022487/14533800

Gelfuso, A., \& Dennis, D. V. (2014). Getting reflection off the page: The challenges of developing support structures for preservice teacher reflection. Teaching and Teacher Education, 38, I-II. https://doi.org/l0.1016/j.tate.2013.10.012

Grier, J. M., \& Johnston, C. C. (2009). An inquiry into the development of teacher identities in STEM career changers. Journal of Science Teacher Education, 20, 57-75. https://doi.org/10.1007/s10972-008-9119-2

Guthrie, H. (2010). Professional development in the vocational education and training workforce. (Occasional Paper). National Centre for Vocational Education Research.

Hansman, C. A. (2008). Adult learning in communities of practice: Situating theory in practice. In C. Kimble \& P. Hildreth (Eds.), Communities of practice vol I: Creating learning environments for educators (Vol. I, pp. 293-309). USA: Information Age Publishing.

Harris, I. B. (20II). Conceptions and theories of learning for workplace education. In J. Hafler (Ed.), Extraordinary Learning in the Workplace (pp. 39-62). New York: Springer.

Harrison, J., Lawson, T., \& Wortley, A. (2005). Facilitating the professional learning of new teachers through critical reflection on practice during mentoring meetings, European Journal of Teacher Education, 28(3), 267-292.

Hattie, J., \& Clinton, J. (2008). Identifying accomplished teachers: A validation study. In R.E Stake, S. Kushner, L. Ingvarson \& J. Hattie (Eds.), Assessing teachers for professional certification: The first decade of the National Board for Professional Teaching Standards (pp. 313-344). Bingley: Emerald Group Publishing.

Hoekstra, A., Brekelmans, M., Beijard, D, \& Korthagen, F. (2009). Experienced teachers' informal learning: Learning activities and changes in behaviour and cognition. Teaching and Teacher Education, 25(5), 663-673.

Hoekstra, A., \& Korthagen, F. (20II). Teacher learning in a context of educational change: Informal learning versus systematically supported learning. Journal of Teacher Education, 62(I), 76-92. https://doi.org//0.1177/0022487/I03829/7

Hopper, B. (200I). The role of the HEl tutor in initial teacher education school-based placement. Mentoring \& Tutoring: Partnership in Learning, 9(3), $211-222$.

Jarvis, P. (2004). Adult education and lifelong learning: Theory and practice (3rd ed.). London: RoutledgeFalmer.

Koffeman, A., \& Snoek, M. (20 I). Identifying context factors as a source for teacher professional learning. Professional Development in Education, I-16. https://doi.org//0.1080/19415257.2018.1557239

Korthagen, F. A., \& Kessels, J. P. (1999). Linking theory and practice: Changing the pedagogy of teacher education. Educational Researcher, 28(4), 4-17.

Korthagen, F., Loughran, J, \& Russell, T. (2006). Developing fundamental principles for teacher education programs and practices. Teaching and Teacher Education, 22(8), 1020-1041. https://doi.org/I0.1016/j.tate.2006.04.022

Kyndt, E., Gijbels, D., Grosemans, I, \& Donche, V. (2016). Teachers' everyday professional development: Mapping informal learning activities, antecedents, and learning outcomes. Review of Educational Research, 86(4), IIII-1150. https://doi. org/10.3102/0034654315627864

Kwakman, K. (2003). Factors affecting teachers' participation in professional learning activities. Teaching and Teacher Education, 19(2), 149-170. https://doi.org/10.1016/S0742-05IX(02)00101-4

Lucas, B., Spencer, E., \& Claxton, G. (2012). How to teach vocational education: a theory of vocational pedagogy. London: City \& Guilds Centre for Skills Development. https://doi.org/I0.13140/2.1.3424.5928

Maxwell, B. (2010). In-service initial teacher education in the learning and skills sector in England: Integrating course and workplace learning. Vocations and Learning, 3, I85-202. https://doi.org// 0.1007/s I2186-010-9045-2

McDonald, M., Kazemi, E, \& Kavanagh, S.S. (2013). Core practices and pedagogies of teacher education: A call for a common language and collective activity. Journal of Teacher Education, 64(5), 378-386. https://doi.org// 0.1 I77/0022487/13493807

McNaughton, S. M., \& Billot, J. (2016). Negotiating academic teacher identity shifts during higher education contextual change. Teaching in Higher Education, 2I(6), 644-658. https://doi.org/I0.1080/13562517.2016.1163669

Messman, G., Mulder, R. H. \& Gruber, H. (2010). Relations between vocational teachers' characteristics of professionalism and their innovative work behaviour. Empirical Research in Vocational Education and Training, 2(1), 21-40. https://www. pedocs.de/volltexte/2012/5234/pdf/ERVET_20I0_I_Messmann_et_al_Relations_between_vocational_teachers_ characteristics_D_A.pdf 
Mezirow, J. (1990). Fostering critical reflection in adulthood: A guide to transformative and emancipatory learning. San Francisco: Jossey-Bass.

Opfer, V. D., \& Pedder, D. (20II). The lost promise of teacher professional development in England. European Journal of Teacher Education, 34(I), 3-24. https://doi.org/I0.1080/02619768.2010.534I3I

Patton, K., \& Parker, M. (2017). Teacher education communities of practice: More than a culture of collaboration. Teaching and Teacher Education, 67, 351-360.

Peercy, M. M., \& Troyan, F. J. (2017). Making transparent the challenges of developing a practice-based pedagogy of teacher education. Teaching and Teacher Education, 61, 26-36. https://doi.org/10.1016/j.tate.2016.10.005

Reaburn, P., \& McDonald, J. (2017). Creating and facilitating communities of practice in Higher Education: Theory to practice in a regional Australian university. In J. McDonald \& A. Cater-Steel (Eds.), Communities of Practice (pp. 121-150). Singapore: Springer.

Retna, K. S., \& Ng, P. T. (20II). Communities of practice: Dynamics and success factors. Leadership \& Organization Development Journal, 32(I), 4I-59. https://doi.org/l0.1108/01437731111099274

Robson, J. (2002). The voices of vocational teachers in the UK: Their perceptions of the nature and status of the further education teacher's professional knowledge. Australian and New Zealand Journal of Vocational Education Research, 10(2), 95 - II3.

Sanchez-Cardona, I., Sanchez-Lugo, J, \& Velez-Gonzalez, J. (2012). Exploring the potential of communities of practice for learning and collaboration in a Higher Education context. Social and Behavioural Sciences, 46, I820-I825.

Shulman, L. S., \& Shulman, J. H. (2004). How and what teachers learn: A shifting perspective. Journal of Curriculum Studies, 36(2), 257-27I. https://doi.org//0.1080/0022027032000148298

Sutherland, L., \& Markauskaite, L. (2012). Examining the role of authenticity in supporting the development of professional identity: An example from teacher education. Higher Education, 64(6), 747-766.

Tang, S. Y. F. (2004). The dynamics of school-based learning in initial teacher education. Research Papers in Education, 19(2), I85204. https://doi.org/10.1080/0267/520410001695425

Tang, S. Y. F. (2006). Professional learning in initial teacher education: The construction of the teaching self in the professional artistry of teaching. In M.B. Klein (Ed.), New Teaching and Teacher Issues (p. 51-72). New York: Nova Science Publishers.

Timperley, H., Wilson, A., Barrar, H., \& Fung, I. (2008). Teacher professional learning and development. France: International Academy of Education.

Trautwein, C. (2018). Academics' identity development as teachers. Teaching in Higher Education, 23(8), 995-1010. https://doi.or $g / 10.1080 / 13562517.2018 .1449739$

Van Driel, J., \& Berry, A. (2012). Teacher professional development focusing on pedagogical content knowledge. Educational Researcher, $4 I(I), 26-28$

Van Lankveld, T., Schoonenboom, J., Volman, M., Croiset, G, \& Beishuizen, J. (2017). Developing a teacher identity in the university context: A systematic review of the literature. Higher Education Research \& Development, 36(2), 325-342. https:// doi.org/l0.1080/07294360.2016.1208154

Viscovik, A. R. (2005). 'Community of Practice' as a framework for supporting tertiary teachers' informal workplace learning. Journal of Vocational Education and Training, 57(3), 389-4I0. https://doi.org/l0.1080/13636820500200293

Wenger, E. (1998). Communities of practice: Learning, meaning and identity. USA: Cambridge University Press.

Zepke, N. (20ll). Understanding teaching, motivation and external influences in student engagement: How can complexity thinking help? Research in Post-Compulsory Education, I6(I), I-13. https://doi.org/I0.1080/I3596748.20 II.54972I 